\title{
PEMANCARAN SINYAL AKUSTIK BUATAN UNTUK MERESPON TINGKAH LAKU IKAN BANDENG (Channos sp.) PADA SKALA PERCOBAAN
}

\author{
Agus Cahyadi \\ Peneliti pada Pusat Riset Teknologi Kelautan, Ancol-Jakarta \\ Teregistrasi I tanggal: 1 Juli 2008; Diterima setelah perbaikan tanggal: 2 Maret 2009; \\ Disetujui terbit tanggal: 16 April 2009
}

\begin{abstract}
ABSTRAK
Salah satu fungsi gurat sisi pada ikan adalah mendeteksi gerakan antar sesama ikan yang diakibatkan oleh faktor lingkungan maupun fisiologi ikan. Tujuan penelitian ini adalah merespon tingkah laku sekumpulan ikan bandeng terhadap sinyal akustik buatan atau SAB. SAB merupakan sinyal yang dibangkitkan dari perubahan fase akustik sebagai nilai perbedaan waktu tunda (delay) yang terjadi pada saat ikan bergerak secara fluktuatif. Melalui penelitian eksperimen, SAB diujicobakan pada skala percobaan dengan mengaktifasi SAB pada perioda $0.01-0.19$ detik dan amplituda-nya adalah $34.6 \mathrm{~dB}$. Pengujian statistik dilakukan untuk dua variabel, yaitu intensitas akustik kuat dan intensitas akustik normal. SAB pada intensitas akustik kuat menunjukan respon yang agresif terhadap tingkah laku kumpulan ikan bandeng pada skala percobaan.
\end{abstract}

KATAKUNCI: $\quad$ sinyal akustik buatan, bandeng, Channos sp, skala percobaan

ABSTRACT: Acoustic of phase shifted activation to respond the milk fish (Channos sp.) behavior at experimental scale, By: Agus Cahyadi

One of linea lateralis function of fish is to detect the motion among fishes which caused by environment factor or fish physiology. The goal research is to respond the schooling fish behavior that artificial acoustic signal or SAB. SAB generated from shifted phase acoustic is delayed time occur at fish swims fluctuate. $S A B$ is tested on experimental scale with activating $S A B$ at 0.01 to 0.19 periods and its amplitude is $34.6 \mathrm{~dB}$. Statistic test is conducted for two variables, namely peak and normal intensity of acoustic. They are peak acoustic intensity and normal acoustic intensity. SAB at peak acoustic intensity showed aggressive respond to milkfish schooling behavior on experimental scale.

KEYWORDS: $\quad$ artificial acoustic signal, milk fishes, Channos sp., experimental scale

\section{PENDAHULUAN}

Fish schooling atau sekumpulan ikan didefinisikan sebagai gerakkan ikan yang berenang secara terpolarisasi dan sinkronisasi (Webb et al., 2008). Pada umumnya sekumpulan ikan yang bergerak pada malam hari membentuk formasi menyebar, memperluas bentuk, dan membatasi kumpulan. Fungsi dari fish schooling adalah untuk menghindari serangan predator, mencari makan yang efektif, keuntungan dalam hidrodinamik, migrasi (migration), reproduksi, dan pembelajaran. Semakin panjang ikannya, maka semakin kecil kepadatannya (Picher \& Partridge, 1979). Kepadatan schooling ikan dalam jumlah ikan per unit volume tergantung dari jenis dan panjang ikan (Partridge, 1981).

Pergerakkan sekumpulan ikan dapat dideteksi oleh teknologi instrumen pembangkit perubahan fase akustik (Diponegoro, 2006) yang merupakan modifikasi instrumentasi sistem komunikasi dengan sistem akustik dual beam (Medwin \& Clarence, 1994). Sistem komunikasi seperti radio maupun pemancar yang berkembang saat ini menerapkan teknik perubahan fase (Kukushkin, 2004). Teknik ini memindai gejala pantulan yang dihasilkan oleh suatu obyek yang bergerak, contohnya gerakkan pohon, pergerakkan bangunan, dan lain-lain. Hal yang sama juga dapat diaplikasikan untuk memindai pergerakkan sekumpulan ikan yang berenang di air. Melalui teknologi perubahan fase akustik, fluktuasi sinyal informasi secara tidak teratur merupakan representasi dari profil atau permukaan pantulan dari ikan tersebut. Semakin cepat gerakkan ikan, semakin cepat fluktuasi yang terjadi. Perubahan fase akustik merupakan bahan dasar untuk diaplikasikan pada sistem liukan ikan (Cahyadi, 2004) sebagai sinyal akustik buatan.

Sinyal ini yang diuji cobakan pada sekumpulan ikan bandeng (Channos sp.) sebagai sasaran akustik. Oleh sebab itu, tujuan dari penelitian ini adalah untuk mengetahui respons tingkah laku sekumpulan ikan bandeng terhadap sinyal akustik buatan yang dibangkitkan oleh sistem liukan ikan. 


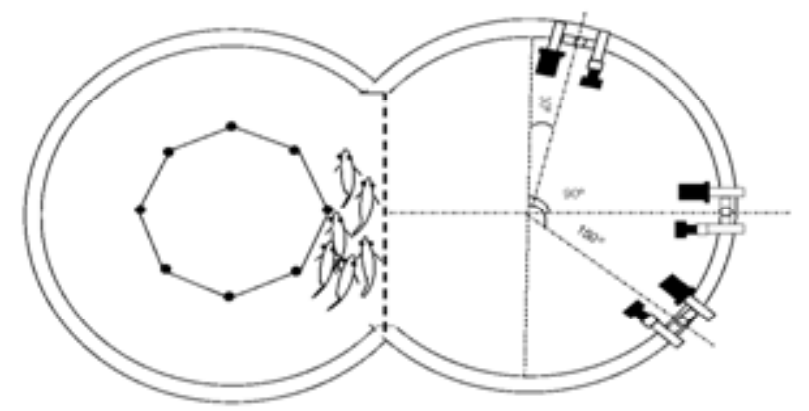

Gambar 1. Penempatan posisi sudut transducer.

Figure 1. Seting transducer angle position.

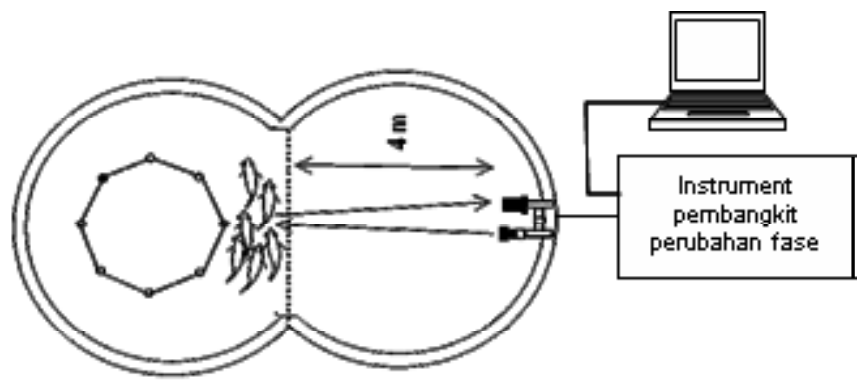

Gambar 2.

Rancangan eksperimen penelitian perubahan fase akustik.

Figure 2.

Experiment design of shifted acoustic phase.

\section{BAHAN DAN METODE}

Penelitian ini dilakukan pada tahun 2008 di kolam milik PT. Bali Melka Lovina, Kabupaten Buleleng Bali. Bentuk kolam menyerupai angka 8 dengan pembatas jaring sampai terbentuk menjadi 2 ruang. Masingmasing ruang mempunyai fungsi yang berbeda. Ruang pertama disi oleh 20 ekor ikan bandeng dengan panjang rata-rata $25 \mathrm{~cm}$ dan di bagian tengahnya terdapat partisi sebagai pengarah gerak ikan. Ruang kedua berfungsi untuk menempatkan instrumen.

Penelitian ini dibagi 2 tahap, yaitu tahap perekaman dan tahap ujicoba hasil perekaman. Masing-masing tahapan menggunakan instrumen dengan sistem dan fungsi yang berbeda. Tahap perekaman digunakan instrumen pembangkit fase untuk menghasilkan perubahan fase akustik dengan pengaturan posisi transducer berdasarkan pada sudut $30^{\circ}, 90^{\circ}$, dan $150^{\circ}$ (Gambar 1). Tahap ujicoba hasil perekaman digunakan sistem liukan ikan untuk menghasilkan sinyal akustik buatan. Untuk mengetahui efektivitas uji coba sinyal akustik buatan terhadap respon tingkah laku sekumpulan ikan bandeng dilakukan pengujian statistik.

\section{Perubahan Fase Akustik}

Gambar 2 memperlihatkan suatu sinyal akustik yang merambat pada suatu media air yang terkena sekumpulan ikan bandeng. Sinyal yang dipantulkan tersebut mengalami perubahan fase pada setiap satuan waktu sesuai dengan morfologi dan laju normal renang ikan tersebut. Berdasarkan pada teori perubahan fase, diformulasikan sebagai berikut:

$$
\phi(t)=C_{1} l(t)+C_{2}
$$

di mana:

$$
\begin{aligned}
f(t)= & \text { perubahan fase akustik yang dipantulkan } \\
\mathrm{l}(\mathrm{t})= & \text { perubahan simpangan sasaran pantulan } \\
& \text { yang besarnya tergantung dari morfologi } \\
C= & \text { kecepatan suara di dalam kolam air laut } \\
& (1.450 \mathrm{~m} / \mathrm{s}) \text { dan laju pergerakkan sasaran } \\
& \text { pantulan }
\end{aligned}
$$

Dari formulasi tersebut pantulan sinyal akustik dari aspek lateral (sisi badan) ikan bandeng secara tunggal mengakibatkan terjadinya perubahan fase dari sinyal yang dipantulkan.

\section{Sinyal Akustik Buatan}

Untuk menentukan jarak pengamatan dan daya yang dibutuhkan oleh sistem liukan ikan didasarkan pada persamaan akustik (Furusawa et al., 1992) berikut ini: 


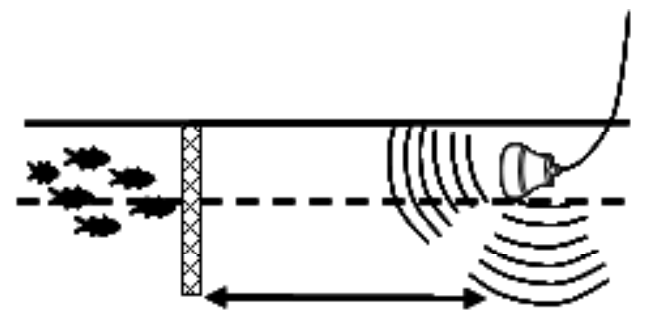

Gambar 3. Sinyal akustik buatan pada sistem liukan ikan yang diujicobakan pada sekumpulan ikan. Figure 3. Artificial acoustic signal on the fish wriggle system tested for schooling fish.

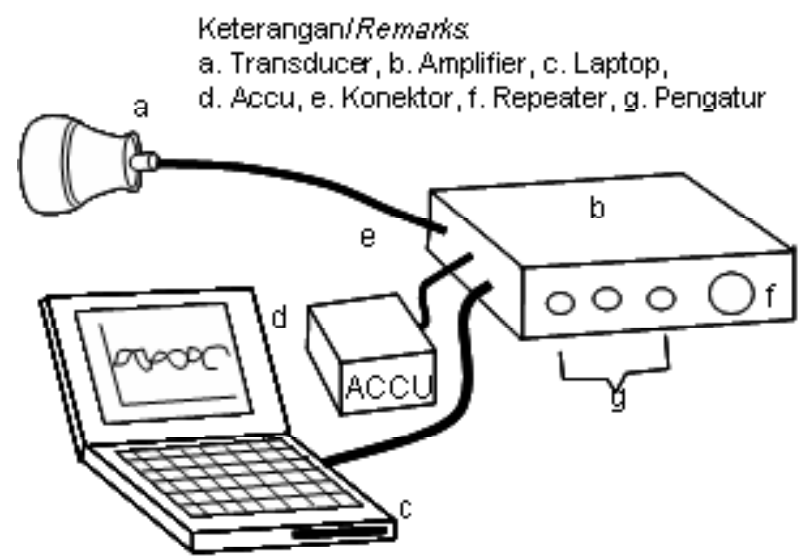

Gambar 4. Konfigurasi sistem liukan ikan dan pendukungnya.

Figure 3. Configuration of the fish wriggle system and its supporting.

di mana:

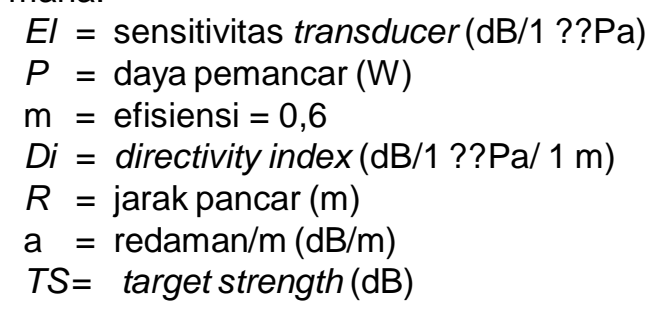

Besarnya target strength tergantung pada jenis ikan. Pada umumnya, beberapa jenis ikan mempunyai target strength yang sama, sedangkan besar Didan El tergantung pada transducer dan frekuensi yang digunakan (Gambar 3 dan 4).

\section{Uji Statistik}

Untuk mengetahui efektivitas sinyal akustik buatan yang dibedakan atas intensitas akustik kuat dan normal dilakukan uji-t (Dajan, 1984). Indikator sekumpulan ikan bandeng dapat merespon sinyal akustik buatan yaitu apabila kumpulan ikan mendekati sumber akustik tersebut. Pengamatannya dilakukan secara habituasi melalui teknik fotografi kepada ikan di sekitar sumber sinyal akustik buatan dengan total waktu pengamatan selama 30 menit dalam 5 kali ulangan berjarak $4 \mathrm{~m}$ dari sasaran. Dalam pengujian ini ditentukan 2 variabel, yaitu intensitas akustik normal dan intensitas akustik kuat. Respons uji coba dilakukan pada taraf nyata $1 \%$. Uji-t ini dikatakan dalam persamaan di bawah ini:

$$
t_{-} h i t=\frac{\bar{X}_{t p}-\bar{X}_{t s}}{S_{-} \operatorname{dev} * \sqrt{\frac{1}{n p}+\frac{1}{n s}}}
$$

di mana:

$\begin{array}{lll}\overline{X_{t p}} & = & \text { rata-rata intensitas kuat } \\ \overline{X_{t s}} & = & \text { rata-rata intensitas normal } \\ \mathrm{np} & = & \text { intensitas akustik kuat } \\ \mathrm{ns} & = & \text { intensitas akustik normal }\end{array}$

\section{HASIL DAN BAHASAN}

Sistem liukan ikan adalah instrumen yang dirancang untuk mengembalikan suara ke lingkungan yang memanfaatkan perubahan fase akustik dari instrumen pembangkit fase akustik. Perubahan fase akustik dapat merepresentasikan liukan renang ikan.

Grafik spektrogram adalah kumpulan data diskrit yang dibentuk oleh ordinat $x$ sebagai fungsi waktu dalam satuan second (ms) dan ordinat y dibentuk dari intensitas suara/amplitudo dalam decibel (dB). 
Proses perekaman sinyal akustik dengan instrumen pembangkit fase akustik menggunakan nilai bit resolution 16 bit dan kemampuan audionya adalah mono. Sedangkan proses penyeleksian dan kuantifikasi frekuensi menggunakan sample rate 44,1 $\mathrm{kHz}$.

Kumpulan ikan bandeng mengalami tahapan tertentu sebelum masuk ke kolam percobaan. Hal ini untuk menghindari gejala shock movement atau pergerakkan tiba-tiba yang dapat mengganggu instrumen yang diatur sebelumnya. Selama 1 minggu kumpulan ikan ini dapat mengenali kondisi kolam. Secara fisiologis, kemampuan kumpulan ikan ini beradaptasi dengan lingkungannya jauh lebih cepat, dikarenakan ikan ini mampu beradaptasi dengan salinitas yang rendah.

Akuisisi sinyal perubahan fase akustik yang direkam oleh instrumen pembangkit fase melalui transducer dilakukan 3 kali pengambilan data. Posisi transducerpada instrumen tersebut membentuk sudut $30^{\circ}, 90^{\circ}$, dan $150^{\circ}$ pada jarak $4 \mathrm{~m}$ dari bibir kolam. Posisi dari ketiga sudut ini untuk menghasilkan pola penerimaan sinyal akustik dari 20 ekor ikan bandeng. Sasaran pemancaran akustik diarahkan pada posisi lateral ikan. Kondisi ini terbentuk manakala kumpulan ikan membentuk formasi gerakkan secara beraturan (sinkronisasi).

Waktu perekaman dilakukan selama 30 menit untuk ketiga sudut yang berbeda dengan rata-rata kapasitas datanya mencapai 1,2 MB. Prosedur perekaman dimulai ketika kumpulan ikan bandeng melintasi tepat mengenai beam transducer (straight line). Tidak selamanya kumpulan ikan bandeng berenang membentuk sinkronisasi gerakkan searah atau berlawanan dengan jaring yang ditempatkan di tengah kolam sebagai pengarah renang. Hal ini dikarenakan oleh fisiologis ikan tersebut terhadap penyesuaian habitat. Namun demikian, perekaman sinyal pantulan akustik dari kumpulan ikan bandeng yang melakukan gerakkan secara sinkronisasi yang dijadikan acuan untuk sinyal akustik buatan.

Gambar 5 memperlihatkan 3 spektrogram yang bersusun secara berurutan dengan bentuk gelombang hasil perekaman dari gerakkan kawanan ikan bandeng. Dari 3 kali percobaan dihasilkan skala waktu 0,01-0,19 detik dan skala amplituda 34,6 dB. Skala waktu ini menunjukkan bahwa kumpulan ikan bandeng yang membentuk sinkronisasi gerakkan renang secara sempurna. Skala amplituda ini menunjukkan bahwa adanya sinkronisasi gerakkan renang ikan disebabkan oleh liukan badan (wriggle) yang ditentukan oleh dimensi badan ikan dan komposisi sirip ikan di dalam kumpulan.

Ploting spektrogram masing-masing sudut transducer dikelompokkan dalam 1 kelompok sampai dengan terbentuk 3 baris spektrogram. Hal ini menunjukkan suatu perbedaan pola sinyal perubahan fase akustik dari 20 ekor ikan bandeng yang pergerakkan sinyalnya ke arah kanan sesuai dengan laju pergerakkan ikan yang berada pada lintasan. Pada sudut $90^{\circ}$, kerapatan sinyalnya dalam 1 track waktu membentuk 2 puncak dan 2 lembah serta intensitasnya lebih stabil. Sinyal ini merepresentasikan bahwa 20 ekor ikan dapat mempertahankan kerapatan di antara ikan. Untuk sudut $30^{\circ}$, track waktunya mempunyai persamaan dengan sudut $150^{\circ}$, tetapi intensitasnya berfluktuatif yang diakibatkan oleh adanya distorsi. Perbedaan yang terlihat nyata ditunjukkan juga pada spektrogram untuk sudut pengujian $30^{\circ}$, sinyal akustiknya sangat berfluktuatif. Penyebab distorsi dikarenakan arah
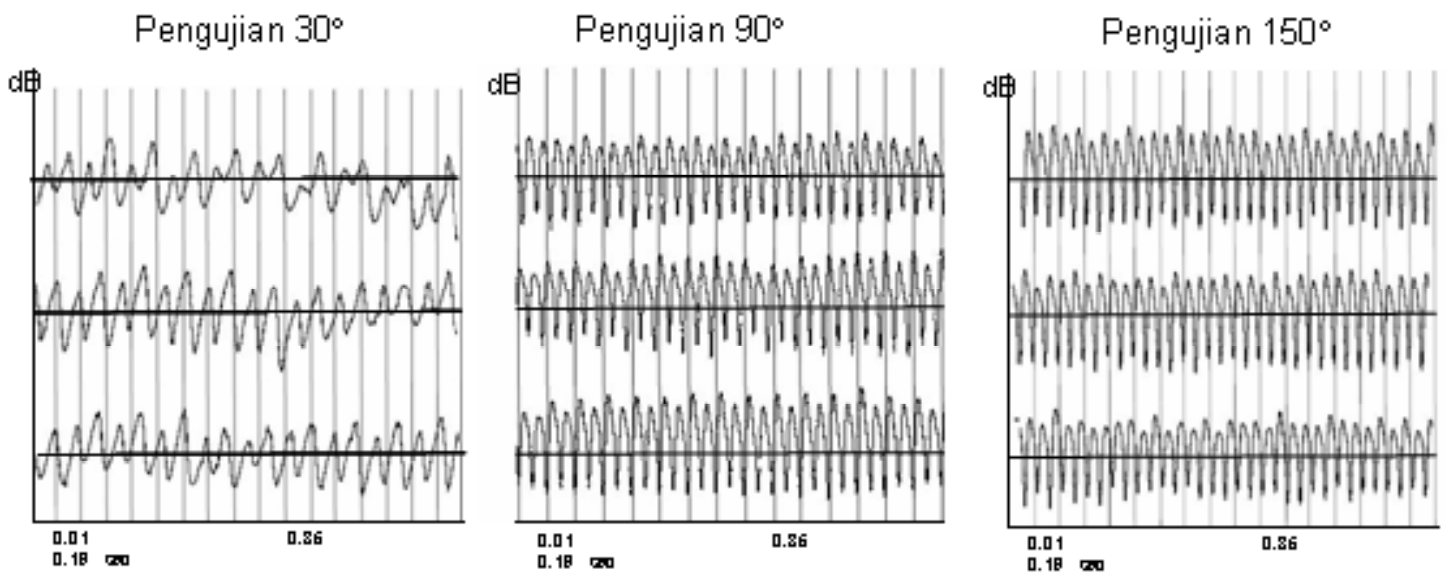

Gambar 5. Tiga kelompok jenis spektrogram hasil perekaman dari instrument pembangkit fase. Figure 5. Three groups for spectrogram of generated phase instrument result. 
beam transducer dan posisi ikan tidak tepat pada bidang pancaran transducer sehingga menimbulkan gangguan sinyal yang berfluktuatif. Penyebab lainnya adalah sinyal yang mengalami pelemahan energi (transmission loss) dapat mempengaruhi hasil perekaman ke receiver transducer meskipun sudah dilengkapi dengan penguat frekuensi balik (receiver amplifier).

Kelompok data pada pengujian sudut $150^{\circ}$ merepresentasikan bahwa kerapatan antar ikan tidak seragam. Artinya posisi antar ikan tidak berada pada lajur yang segaris. Sedangkan pada pengujian sudut $30^{\circ}$ kerapatan antar ikan sangat lebar dan saling berjauhan sehingga hasil penerimaan sinyal akustik ikannya banyak dipengaruhi dari faktor yang lain, seperti pantulan dengan dinding kolam atau pantulan dari sebagian kumpulan ikan.

Data perekaman sinyal akustik dari kumpulan ikan bandeng merupakan material yang akan diujicobakan sebagai sinyal akustik buatan (artificial acoustic signal) dengan sistem liukan ikan. Data sinyal akustik buatan yang digunakan untuk uji coba efektivitas merupakan data yang stabil dan tidak mengalami distorsi yang besar, yaitu pada sudut $90^{\circ}$. Sinyal akustik buatan ini diuji cobakan pada kumpulan ikan bandeng di kolam percobaan bersekat dengan sistem liukan ikan. Waktu pemancaran akustiknya selama 30 menit dengan posisi transducer terhadap lintasan ikan membentuk sudut $90^{\circ}$. Untuk mengetahui respon tingkah laku kumpulan ikan bandeng terhadap sinyal akustik buatan ini dibuktikan dengan mendekatnya ikan tersebut ke arah sumber sinyal akustik buatan. Dengan kata lain, ikan akan bergerak ke arah sinyal akustik buatan setelah melewati celah sempit tanpa jaring di antara 2 ruang pada kolam percobaan. Pada saat itu, juga dilakukan pengambilan foto dengan cara mengatur jarak antara kamera dengan kondisi ikan tersebut.

Uji efektivitas sinyal akustik buatan terhadap respons tingkah laku ikan dilakukan dengan membandingkan 2 variabel yaitu intensitas akustik normal, mengacu pada amplituda $34,6 \mathrm{~dB}$ dan intensitas akustik kuat. Intensitas akustik kuat dilakukan dengan cara meningkatkan gain 2 kali lipat dari intensitas normal, yang nilainya 69,2 dB.

Setiap varibel dibagi ke dalam 6 pembagian skala waktu yang jedanya 5 menit sekali untuk proses aktivasi sinyal akustik buatan. Awal proses penghitungan dimulai dari tahap awal pemancaran sinyal akustik buatan selama 30 menit dalam 5 kali ulangan. Setelah itu, diamati apakah ikan mendekati sumber sinyal akustik buatan atau tidak.
Untuk mengetahui 2 nilai variabel berbeda nyata dari sinyal akustik buatan ini, digunakana nilai ratarata selama 5 hari untuk variabel intensitas akustik kuat 17,67 ekor dan untuk nilai rata-rata intensitas akustik normal 9,35 ekor. Nilai t-hitung pada taraf kepercayaan $99 \%(a=0,01)$ adalah nilainya lebih besar daripada t-tabel, yaitu 3,35686. Dari kedua nilai ini menunjukkan bahwa aktivasi sinyal akustik buatan yang dioperasikan pada intensitas akustik kuat dengan nilai $69,2 \mathrm{~dB}$, nilai rata-rata tingkah laku dalam merespons sinyal akustik buatan lebih besar daripada intensitas akustik normal. Jadi terdapat perbedaan apabila dioperasikan pada intensitas akustik yang berbeda.

\section{KESIMPULAN DAN SARAN}

\section{Kesimpulan}

1. Posisi sudut pemancaran sinyal akustik buatan yang dibangkitkan oleh sistem liukan ikan $90^{\circ}$. Posisi ini merupakan posisi optimal untuk mengaktivasi pemancaran sinyal akustik buatan yang diarahkan pada sekumpulan ikan. Spektrogram dari sinyal akustik buatan ini mempunyai skala waktu 0,01-0,19 detik yang dioperasikan pada intensitas akustik kuat dengan nilai $69,2 \mathrm{~dB}$ dan intensitas akustik normal dengan nilai 39,6 dB.

2. Pengujian efektivitas sinyal akustik buatan dilakukan melalui pendekatan statistik dengan menggunakan kedua variabel di atas. Dari hasil pengujian menunjukkan intensitas akustik kuat mempunyai nilai yang signifikan untuk merespons tingkah laku ikan bandeng di kolam percobaan.

\section{Saran}

1. Pengujian sinyal akustik buatan membutuhkan ikan contoh lebih banyak untuk mengidentifikasi lebih detil respons tingkah laku.

2. Sinyal akustik buatan diujicobakan di laut meskipun dirancang instrumen baru untuk mengeliminir continues wave.

3. Penelitian ini baru diujicobakan di kolam sehingga membutuhkan ujicoba lebih lanjut untuk menyempurnakan instrumen melalui meningkatkan powerdan log book data perubahan fase akustik. 


\section{PERSANTUNAN}

Kegitan dari hasil riset mandiri, Indonesia T. A. 2008 di Departemen Elektro, Universitas Indonesia. Saya ucapkan terima kasih kepada Dr. Arman Diponegoro yang telah meminjamkan instrumen pembangkit perubahan fase dan kepada PT. Bali Melka Grup yang telah menyediakan kolam ikan bandeng 20 ekor. Ucapan terima kasih juga diucapkan kepada teknisi yang telah membantu dalam penelitian ini.

\section{DAFTAR PUSTAKA}

Cahyadi, A. 2004. Aplikasi alat pemanggil ikan di sekitar terumbu karang. Jurnal Teknologi Kelautan 6: 86-90.

Dajan, M. 1984. Teknik Pengambilan Data Statistik. Gajah Mada Press. Yogyakarta.

Diponogoro, A. 2006. Aplikasi perubahan fase akustik dan analisis hidden markov untuk schooling ikan. (Disertasi tidak dipublikasikan). Institut Pertanian Bogor.
Furusawa, M. H., J. I. Takao, Y. C. Miyonohana, \& S. I. Kawaguchi. 1992. Two-step echo integration method for accurate estimation of fish abundance. Nippon Suisan Gakkaishi. 58: 469- 475.

Kukushkin, A. 2004. Radio Wave Propagation in the Marine Boundary Layer. Wiley-VCH Verlag GmbH and Co. KGaA. Weinheim. Germany.

Medwin, H. \& S. C. Clarence. 1994. Fundamentals of Acoustic Oceanography. Academic Press Ltd. San Diego. USA.

Picher, T. J. \& B. L. Partridge. 1979. Fish schools density and volume. Marine Biology. 54: 383-394.

Partridge, B. L. 1981. Internal dynamics and interrelations of fish in schools. Anim. Behav. 30: 298-299.

Webb, J., N. A. Popper, \& R. F. Richard. 2008. Fish Bioacoustic. Kingston. University of Rhode Island. USA. 